Part I. Diseases and problems distinguished by WHO and FAO

Dział I. Choroby i problemy wyróżnione przez WHO i FAO

\title{
AM I THIN ENOUGH? AN INTRODUCTION TO ANOREXIA NERVOSA. FACE OF THIS EATING DISORDER IN POLAND
}

\section{CZY JESTEM WYSTARCZAJACO SZCZUPŁA(Y)? WSTEP DO PROBLEMATYKI JADŁOWSTRETU PSYCHICZNEGO. OBLICZE TEGO ZABURZENIA ODŻYWIANIA W POLSCE}

\author{
Adrian Rzepko $^{1(\mathrm{E}, \mathrm{F})}$, Paulina Osińska ${ }^{2(\mathrm{E}, \mathrm{F})}$, Marta Makowska $^{2(\mathrm{E}, \mathrm{F})}$ \\ ${ }^{1}$ University of Warsaw, Poland \\ ${ }^{2}$ Warsaw University of Life Sciences, Poland
}

\begin{abstract}
Authors' contribution Wkład autorów:

A. Study design/planning zaplanowanie badań

B. Data collection/entry zebranie danych

C. Data analysis/statistics dane - analiza i statystyki D. Data interpretation interpretacja danych E. Preparation of manuscript przygotowanie artykułu F. Literature analysis/search wyszukiwanie i analiza literatury G. Funds collection zebranie funduszy
\end{abstract}

Tables: 0

Figures: 0

References: 37

Submitted: 30.11 .2015

Accepted: 21.04.2016

\section{Summary}

Anorexia nervosa is a serious and potentially life-threatening eating disorder. Persons, who struggle with this problem, consciously starve and quickly lose weight. It is one of the most common mental disease among young women. The following article is an introduction to the anorexia issue. It presents a definition of anorexia, its historical background, a discussion about its causes and ways of treatment. The knowledge of anorexia as well as its risk factors is essential to take appropriate measures connected with the help for the ill people. Anorexics, who discern their disease and understand related to it dangers for their health and lives, undergo treatment more willingly. The following text shows recent Polish research and discusses the anorexia problem in this country. This article also presents a controversy over polish Pro-Ana movement.

Keywords: anorexia nervosa, Pro-Ana Movement, eating disorder, prevalence, Poland

\section{Streszczenie}

Jadłowstręt psychiczny to poważne, a także potencjalnie zagrażające życiu, zaburzenie odżywiania. Osoby, które walczą z tym zaburzeniem, świadomie głodzą się oraz w szybkim tempie tracą wagę. Jest to jedna $\mathrm{z}$ najczęstszych chorób psychicznych występujących wśród młodych kobiet. Poniższy artykuł to wstęp do problematyki związanej z anoreksją. Przedstawia on definicje anoreksji, jej tło historyczne, dyskusje na temat jej przyczyn oraz metody leczenia. Wiedza na temat anoreksji, a także czynniki ryzyka, są podstawą do podejmowania odpowiednich środków związanych $\mathrm{z}$ zapewnianiem pomocy osobom na nią cierpiącym. Anorektycy, którzy uznali swoją chorobę i są świadomi związanych z nią zagrożeń dla zdrowia i życia, chętniej podejmują się leczenia. Poniższy tekst ukazuje ostatnie badania prowadzone $w$ Polsce oraz omawia problem anoreksji $w$ tym kraju. Ten artykuł prezentuje także kontrowersje wokół polskiego ruchu Pro-Ana.

Słowa kluczowe: jadłowstręt psychiczny, Ruch Pro-Ana, zaburzenie odżywiania, zapobieganie, Polska

\section{Introduction}

Anorexia is an extensively discussed problem both in Polish [1-3] and world literature [4-6]. This issue is constantly mentioned in the media [7], causing many controversies and often intensive discussions. Anorexia can be defined as follows: 'Anorexia Nervosa (AN) is a deeply perplexing illness that ravages both mind and body. AN is the visible eating disorder, universally associated with emaciation and commonly accompanied by marked increases in physical activity.' [8]. Many people suffering from anorexia perceive themselves as overweight, even though they are underweight. For they have a distorted cognition about themselves as well as low self-esteem. Eating becomes difficult for these people and they usually eat very small portions of only certain food, and weighing starts to be an obsession.

For many years eating disorders have been associated with specific professional groups, e.g. dancers, models, jockeys. These problems have been also related to the culture of highly-developed countries, such as the USA,

Rzepko A, Osinska P, Makowska M. Am i thin enough? An introduction to anorexia nervosa. Face of this eating disorder in Poland. Health Problems of Civilization 2016; 10(3): 7-14. doi: 10.5114/hpc.2016.61359.

Address for correspondence / Adres korespondencyjny: Adrian Rzepko, University of Warsaw, Institute of Sociology, Karowa 18, 00-927 Warsaw, Poland, e-mail: kaadpo@gmail.com, phone +48 228278599

Copyright: (C) 2016 Pope John Paul II State School of Higher Education in Biała Podlaska. This is an Open Access journal, all articles are distributed under the terms of the Creative Commons Attribution-NonCommercial-ShareAlike 4.0 International (CC BY-NC-SA 4.0) License (http://creativecommons.org/licenses/by-nc-sa/4.0/), allowing third parties to copy and redistribute the material in any medium or format and to remix, transform, and build upon the material, provided the original work is properly cited and states its license. 
Canada, Japan or West Europe [9]. However, it has become clear in the near past that such a disease does not only concern uniquely specific professions or countries. Promoted by the media, a slim silhouette and a pursuit of it can result in a disease of people in every part of the world, even in African countries like Kenya or Ghana [10,11]. It is not a surprising fact that it appears also in postcommunist Poland.

People generally suffer from anorexia at the age from 12 to 35 , where the maximum intensity of this disease occurs at the age from 15 to 19 [9]. Eating disorders usually start during adolescence (age: 11 - 13 years). Such disturbances intensify in the following years. It is connected with the fact that at this period of time body weight as well as an interest of own appearance increases, especially among girls. A significant contribution to it has the aim of achieving a commonly promoted image of a slim silhouette [12].

Such disease occurs more frequently among women than men. The analysis of international data indicates that during the lifetime between $0.3 \%$ and $1.5 \%$ of women suffer from anorexia, where among men it is between $0.1 \%$ and $0.5 \%[13]$.

\section{Anorexia nervosa in historical background}

Anorexia nervosa had its clinical equivalents in different historical epochs [14]. First unclearly described cases, reminiscent of anorexia because of occurring symptoms, happened between the 5th and 8th centuries AD as well as at the time of early Christianity. They were consistently considered as connected with possession of evil forces, for which exorcisms were the only effective remedy [15].

In 1689 a British physician, Morton, described a combination of factors connected with the disease entity that can be diagnosed as anorexia nowadays. These factors were: loss of appetite, constipation, absence of menstrual cycles, lack of interest in own health and life. Morton used a term 'nervous consumption' and he thought that he was describing a strain of tuberculosis which occurring without a high temperature and dyspnea. In 1859 in the USA Chipley published an article about 'sitomania' - a fear of eating [14]. First directly use of the term 'anorexia nervosa' to describe eating disorders was placed in medical literature not until 1874 by Gull [15].

Between the 16th and 19th centuries there was described a disease, called chlorosis, which was similar to anorexia. It was characterized by lack of appetite, secondary amenorrhea, nausea, vomiting, binge, fear of obesity, typical greenish skin color, loss of weight which resulted sometimes in death. It was a disease of wealthy people [14].

Bella's research from 1985 was based on the study of the lives of 261 holy people living in the area of Italy. It helped him to distinguish another type of anorexia which he named 'holy anorexia'. It consisted of a refusal to eat any nourishment as a superior force's order. Starving girls were perceived as divinely appointed because of their ability to maintain a relatively normal health condition while consuming hardly any repasts. They could even become 'a tourist attraction for the curious and a source of inspiration for religious pilgrims' [15]. Such disorders evoked the interest among people, 'they were accompanied by the atmosphere of interest, uniqueness and mysteriousness' [16]. In the 18th, 19th and even at the beginning of 20th centuries there were organised the displays of 'alive skeletons' as well as exorcisms were performed on people who had an aversion to eating. Even in 1976 in Bavaria during exorcism there was a case of the death of a woman whose body was extremely devastated by starvation [16]. However, it was only a single case. Some authors claim that before the 20th century AN was a way of having an influence on surroundings like family, neighbours as well as wider society. Only after the second world war it started to be combined with the distorted body image as well as it became a cultural feature [16]. Despite not a very good economic situation after the war, in Poland also cases of eating disorders occurred. It can be illustrated by the following quote of Iwasiow's novel: 'Magdusia is looking at triples, swallowing saliva. She is swallowing not because of the appetite stimulant. She is swallowing in order not to vomit (...) Functional anorexia (nobody knows this disease). Poor eater, Tadek - poor eater, that is it called. And it shames children. Because the war was recently. The imperialists are ready for the next one. Let's eat where there is still time' [17].

Researchers from all over the world have not been successful in defining if certain historical periods brought greater or lesser intensification of anorexia nervosa. However, undoubtedly it is the 20th century fashion for slim silhouette caused the increasing incidence of such disease. It was contributed by the following factors: change of family model, where a child starts to lead a central role, earlier maturation among girls, change of women role, emphasising the meaning of sexuality and ideal of beauty that has been a slim body shape [16].

\section{Symptoms and causes of anorexia nervosa}

It is complicated to indicate unambiguous factors causing anorexia. It can be observed, inter alia, in the differences of their classification by individual researchers facing this issue. They have focused on various 
aspects causing this eating disorders [5]. By the year 1972 anorexia was affirmed on the basis of criteria created by Feigner and his co-workers. AN was recognized when the total weight of body decreased by $25 \%$ in regard to the previous one. The examined person characterized by an unnatural attitude toward nutrition as well as atypical cognition about body weight. At the same time mental disorders did not occur and afflictions connected with weight loss were excluded [18]. Such an approach to the issue can be illustrated by the following example from the blog of one person suffering from anorexia: 'I fainted today at school. And there was... a phone to my mum, an ambulance, and a hospital. Such a disaster. They affirmed that I was dehydrated. There was nothing about the weight... which means that I should lose weight much more.' [19]. Another blogger writes about her disease as following: 'I am still lying. I lie to everybody around, myself and my body. Have you, my belly, eaten dinner? Multivitamin was for dinner. And for dinner there will be apple sage. A food supplement. A preparation cannot be used as a substitution of a varied diet - Do you want to bet?' [20].

Nowadays in the USA as well as in other countries Diagnostic and Statistical Manual of Mental Disorders created by American Psychiatric Association is helpful in the identification of AN. For Nogal and Lewiński the most significant criteria, which were mentioned there, are: 'the refusal to maintenance of the minimum of weight appropriate for the age and height of an ill person, strong fear of the gain of body weight or obesity, in spite of mass deficiency, distorted perception of own body shape, the absence of menstrual cycles' [2].

Fairburn and others in the analysis on the basis of the previously done research, identify the following factors causing anorexia: obesity which appeared before, occurrence of anorexia or other eating disorders in family, mood disorders, manic-depressive syndrome, being too much concerned about own appearance and weight, overusing psychoactive drugs, previous unpleasant events and situations, perfectionism and negative self-assessment [5].

The level of energy and a desire to life decrease with the progression of a disease. Such a person is able to separate himself or herself from friends, family, and to fully concentrate on sport. Physical activities are known as one of the way of losing calories therefore it is main aim of anorectics [21]. To illustrate it, the following utterance of an ill person can be quoted; '(...) I had to resign from vegetarianism after three months when mum imposed a condition - vegetarianism or sport. Obviously I started eating meat. But it does not mean that I finished losing my weight. Firstly I reduced breakfasts, then branches, I nibbled something for dinners. I did not only resign from suppers. Practically, it was my only one repast. In such nutrition I did plenty of sports like tennis, skiing, cycling, gymnastics. I knew by heart almost all diabetic tables. I quickly managed to gain a desirable weight which was 48 kilograms. But it did not change anything. I was afraid that I could again put on weight so I give up eating sweets, potatoes etc. I ate only accompanied by others - I did it just for show (...)' [21].

It is known for many years now that one of the reasons of the anorexia occurrence is social pressure as well as fashion for a slim silhouette [6]. The results of Garner and Garfinkel's research indicated that AN occurs most frequently among persons associated with the dance and fashion world. They claimed also that American beauty image has 'lost it's weight' from the second half of 20th century and popular women's magazines have published more and more articles regarded to the methods of become thin. On the basis of data they concluded that eating disorders are most common among young women because they are particularly vulnerable to accept beauty models established in a given culture [6]. Not all research agree that anorexia is an issue connected with the culture. Keel and Klump write: 'Although cultural factors such as increasing idealization of thinness may influence rates of AN, such factors seem neither sufficient nor necessary' [15]. They claim that the expansion of western culture with all the forms of industrialization undoubtedly evoke certain changes of thinking which after consolidation can cause anorexia. However that does not have to be strictly necessary to induce AN. The evidence of it is the fact that this disease appears at the same level of intensity in cultures, which are completely not related to western world, and in different historical epochs (see point 2) with different canon of beauty. The authors start also a discussion about what is the role of gens in this illness [15].

Polish researchers, Nogal and Lewinski, consider that 'anorexia nervosa is a syndrome of the area from medicine, psychology and sociology' [2]. In their elaboration of the literature on this subject, they indicated that the twins studies, which were done in order to verify the significance of genetic factors in the prevalence of anorexia, show that among identical twins such compatibility happens in both children in $44-57 \%$ of cases, while among fraternal twins it occurs in $3-12.5 \%$ of cases. The research of twins and families nutrition disruptions helped to estimate the risk of inheriting diseases connected with eating disorders. Nowadays, it is announced that ' $50-80 \%$ of variability in the susceptibility to AN depends on genetic factors' [2].

A specific family situation of many anorectics can be treated as a cause of occurring this disease. Although, the researchers differ on this opinion, they sometimes regard family relations as the anorexia effect [2]. The analysis of literature, which was done by Nogal and Lewinski, showed that relations in family have the following nature: a dominant mother and a passive father, communication disorders, not taking under consideration the 
child's pursuit of being independence or autonomous. Wlodarczyk-Bisaga indicates that an ill person discovers he or she has got a particular power over friends or parents by starving [14].

Thus, a disorder like AN is caused by a wide range of factors. The researchers of this issue are not able to unambiguously indicate which contributor is the most significant: is it caused by mental problems of the individual, family problems, gens or is it an issue related to culture and society. Each of these factors probably plays its role, though it can vary from ill persons.

Introducing a differentiation between anorexia and bulimia (binge-eating syndrome) seems to be meaningful. In an anorexia case there is a refusal to eat, while in a bulimia case ill persons eat rapidly huge amounts of food and then they vomit because of feeling guilty. Bulimics mostly consume sweets and highcalorific dishes. They can eat even 6,000 calories at once [22]. Here are the statement of a person who dealt with this disease: 'It is like there was something inside taking control over me and opening the door of a pantry. I do not think what I do. It just happens, it happens really fast. When I binge, I don't know what I eat and I don't care. I know only that I never have enough.' [22]. The researchers do not always regard bulimia as autonomous disease entity because of the fact that $47 \%$ of examined persons, who had diagnosed anorexia, have also distinguished bulimic behaviour [23].

\section{Process of anorexia nervosa treatment}

Various studies give a different number of persons who recuperate from eating disorders. They are accounts from $40 \%$ to $77 \%$. A partial recovery can be observed from several percent to $40 \%$. Thus, about $20 \%$ of patients have a chronic course of a disease [24].

Basic purpose in the fight against AN is teaching patients how they have to eat and deal with own emotions. Nothing can be achieved without a cooperation with an ill person. To recover from anorexia there is also needed help and support of close ones. The 'healing' process is not easy [23]. It is not only disturbed by deep cachexia but also by a patient's psyche. Anorexics have a tendency to deny that there is something bothering them [21]. In their self-consciousness, they are terrified of gaining weight [21], which considerably impedes the treatment. The process of getting used to again 'normal' eating (providing a human organism with the right amount of calories in order to ensure the proper functioning of a body) is difficult. It lasts very long. There is no assurance that such a person after some time and gaining little weight will not comes back again to old habits. Treatment requires a cooperation with several specialists like doctors, diabetics and psychologists [2]. The Jaworska's research has shown that the level of readiness to start treatment among women is positively related to the level of knowledge about methods, treatment process as well as health complications that are associated with AN [25].

Analyzing different research, Nogal and Lewinski have indicated negative health effects of this disease. Numerous metabolic and hormone disturbances appear among ill persons. Anorexia results in deep depression, which is estimated that it occurs in $25-88 \%$ of patients. There are also anemia, secondary amenorrhea, while osteoporosis is diagnosed in $25-50 \%$ of tested ill persons. There can also appear hypoglycemia [2]. Additionally, among patients there can also occur slow metabolism, slowed heart rate, insomnia, chronic kidney problems, dizziness, syncope, brittle hair and nails, problems with digestive system including constipation, diarrhea, flatulence, dehydration, tiredness [26].

Hospitalization of anorexics is an ultimate solution, when other forms of help (e.g. outpatient care) did not provide any improvements. Patients most frequently are placed in a child and adolescent psychiatric ward. This method of treatment is based on a combination of behavioral, systemic as well as cognitive or psychodynamic approach. Pharmacological treatment is included while with anorexia coexists with symptoms of mental diseases [27].

The most reasonable method of treatment in advanced anorexia is psychotherapy [23]. The best conditions for psychotherapy are outside hospitals. In hospitals patients are fed by force in order to complete nutrient deficiencies which is essential for the right functioning of a body. It is not the most appropriate treatment because everything happens without patients' consent. Moreover, the effects of such a procedure is short-term [23].

The first recovery center for patients with eating disorders in Poland was created in 2010. It is a private medical facility led by the charity 'Drzewo życia' (eng. Tree of Life) in Mława. This is an alternative to hospital treatment, though there are also various regimes. However, the stay of a patient is not associated with social stigmatization as it is in a psychiatric ward.

Data related to mortality is not identical. It is estimated that the death on account of anorexia affects about $5-18 \%$ of ill persons. According to different studies, the standardized mortality ratio (SMR; the ratio of observed to expected deaths) is from 0.71 to 17.8 . Some of the research show that anorexia amongst other mental diseases has the highest mortality rate in a female group [28,29]. About $50 \%$ of anorexics die as a result of suicides 
[2]. Within other reasons there can be listed also: pneumonia, hypoglycaemia, kidney disease, cancer, alcohol intoxication, subdural bleeding, medical problems caused by malnutrition $[28,30]$.

\section{Anorexia in Poland}

There still have not been done any population-based studies about the number of anorexics in Poland. Researchers have presumed that it can be similar to the West countries [2].

In 2008 Kedra and Pietras examined 250 persons who were diverse in terms of the demography. The results of it were extremely alarming because it showed that $62 \%$ of respondents have confirmed eating disorders related to underweight, overweight or obesity. In patients' assessment the main factors causing the disturbances were: promoted eating styles which were published in magazines, adverts of food products in the media as well as fashion of diets. Their research also demonstrated that eating disorders have a tendency to occur in a family [1].

Significantly less alarming were the results of Chytra-Gędek and Kobierecka's research, in which only $6.5 \%$ of 92 examined women in Kuyavia - Pomerania province showed behavior indicating the presence of anorexic readiness syndrome. It revealed itself more frequently among younger people - mainly in the concentrating on body shape and its weight context. These persons used also more often dangerous methods of losing kilograms [3].

Wojtyla et al.'s research, on a representative sample of secondary school students, indicates that $40 \%$ of respondents experienced the fear of obesity. Over a quarter of students declared a desire to reduce their body mass. As many as $33 \%$ of students tried to lose weight using even drastic methods. A feeling of a food aversion declared $28 \%$ of respondents, while every tenth of them informed that they provoked vomiting. The youth seems not to recognize that their physical activity can protect them from unwanted weight as well as it can help to fight with eating disorders. Most of them, 77\%, sneak between meals, and every fourth of them do it at night [31].

Trafalska and others did a research among young people who attended to secondary schools, technical institutes, high schools and vocational schools in Łódź. They demonstrated that $46.7 \%$ of students considered that they weight too much or too less. During the research $13.2 \%$ of tested persons were on a diet about which they know mostly from the Internet. Every fifth of tested students declared himself to be too fat. Almost a half of students considered that underweight is better than overweight. As many as $67.5 \%$ of them thought that a slim silhouette simplifies finding a partner, job and gives satisfaction [12].

Chalcarz and others conducted a research among female students of Department of Tourism and Recreation. Every fourth of them showed a high level of the presence of anorexia readiness syndrome (ARS), and thus also a huge risk of AN. The studies indicated that persons with a high level of anorexia readiness syndrome intensively do exercises and at the same time they reduce the amount of calories in their diet. Such people know the energetic value of many products and they are angry on themselves when they eat too much. They devote a lot of attention to appearance and they compare themselves to persons from the mass media [32].

\section{Pro-ana movement}

A different attitude to anorexia, which can be regarded as controversial, is pro-ana movement (which stand for anorexia). It is a movement which glorifies AN and supports anorexics in losing weight. It claims that anorexia is not a disease but a consciously chosen lifestyle which allows to gain perfection and happiness. This movement emphasizes freedom of women in a choice of how they want to look like and how they want to eat. According to Dias, it is connected with the concept characterized for the third-wave of feminism where the matter of how our body looks like was considered as a key aspect [33]. The representatives of pro-ana movement called anorexia 'a protest against social image of a female body' [33].

The main place where this movement functions is the Internet, for example, blogs, forums that support persons who want to have anorexia. After writing in Polish Google the name 'Polish website pro-ana', there are 585,000 results (October 1, 2015), which reflects the huge amount of websites devoted to this issue in Polish language.

In this surrounding a disease is personalized and it gets a name 'Ana' described as a 'goddess' and also a 'friend'. Members of this movement called themselves 'butterflies' because of the fact that butterfly is recalled with something light and ethereal [34]. A Polish writer of 'Anty pro-ana' blog analysed 288 blogs devoted to pro-ana. She stated following facts: the youngest blogger was 12 years old and the oldest one was 28 years old (the average age was 17.6), the lowest weight was 38.5 kilograms, while the heaviest one was 109 kilograms (the average height was 58.6), the lowest BMI ${ }^{1}$ (Body Mass Index) was 13.5 and the highest one was 38.2 (the

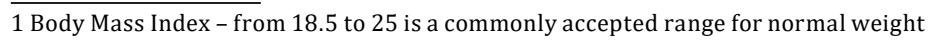


average was 21.2), of the lowest 'target BMI' was 10.9 and the highest one was 24.6 (the average was 16.8). Among tested bloggers 35\% of them provoked vomiting, 33\% regularly used laxative and $21 \%$ of them used other pharmaceuticals [35]. A different and smaller research, based on a sample of 30 blogs, showed that on two thirds of them authors wrote that they used laxatives, diuretics, natural hunger-reducing and improving metabolism medicines. Frequently these remedies are not intended for it. A good example is Sudafed which is a medicine for runny nose with the side effect of increasing metabolism [34]. Use for improper purpose is one of disadvantages of great availability and marketing of medicines [36].

Most of pro-ana websites have similar structure (chats, advice sections, links to similar sites). Their aim is not only a mutual motivation for more and more drastic losing weight, but also they are created in order to search advice how to handle with own disease and how to get over it. It is because these people do not feel understood enough by close friends or non-anorexics [33]. The analysis of Polish pro-ana blogs showed that most frequently there appears 'thinspiration' (which is an inspiration of being thin), mainly in terms of pictures of thin models and actresses. They appeared on more than half of blogs (about 60\%). Later, in every fifth of blogs there was included a Decalogue (consists of 10 commandments like 'Being thin is more important than being healthy', 'Thou shell no eat without feeling guilty' ect.). On the similar amount of websites there were included 40 reasons for which it is worth to be thin. On slightly less websites there were religious elements (e.g. prayers to Anna) as well as pro-ana quotes. On these websites there was rarely (about 10\%) an alphabet of butterflies ('A-anorexia, my queen - a fallen Angel who destroys my soul; B - bulimia, my friend and helplessness that broke into life'). On about 30\% of blogs there were no one of these elements, and therefore they could be regarded as innocent notes about losing weight. Nevertheless, according to the researcher, it was just only first impression [35]. What is more, 'pro-ana followers' do not have to be anorexics. Moreover, only $15 \%$ of the tested blog authors suited to weight grade of anorexia [35]. In another study it was one third of the group [34]. However, the bloggers demonstrate strong similarity to ill persons in terms of 'the way of functioning as well as cognitive and emotional perceptions own body, values allotted to low weight and to personal adjectives' [34]. The existence of pro-ana movement can lead to promoting eating disorders to the larger number of people and result at increasing number of those suffering from anorexia.

The Anorexia Nervosa and Associated Disorders Organization submitted a document to websites working similar like Yahoo in order to remove websites promoting anorexia [33]. In 2013 in Israel, Spain and Italy there was adopted the law forbidding employing too thin models. In 2015 France prepared an amendment of own law which aim was a removal of an anorexia promotion. Except no acceptance to work of thin models whose BMI is lower than 18 it proposed also to recognize websites encouraging to have anorexia as illegal [37]. At present in Poland there are no legal regulations which could limit the existence of such blogs and websites.

\section{Conclusions}

In 1998 World Health Organisation announced the obesity to be a global epidemic. It is a main health problem in the world. It concerns both adults and children. It leads to many civilisation diseases like, for example, cardiovascular diseases or type 2 diabetes [31]. For this reason in the media there is lots of losing weight information and promotion of fit silhouette. This, combined with the lack of education about rational nutrition and care for health can lead, especially among young people, to pathology connected with eating food. To such pathologies belongs anorexia nervosa described in this article. The problem of this disease is exceptionally extensive and it can be possibly seen from different perspectives (e.g. sociologic, psychological and medical). They sometimes mutually exclusive themselves. As an example a social and cultural conditions of anorexia can be a matter of argument. Garner and Garfinkel have shown in their work that there are close ties between anorexia and the propaganda of a slim silhouette trend [6]. Whereas, Keel with Klump doubted in the existence of a bigger link in such area [16].

It is undeniable that anorexia is a mental disease which is a threat to health and life as well as it requires a specified treatment. Anorexics more frequently die as a result of suicides than from the imminent cachexia caused by disturbances. This fact indicates that there is a need to diagnose for depression syndromes or other mental diseases because these people should not be left without any care of specialists.

The treatment requires help from many specialists - not only psychiatrists but also other doctors and diabetes. Hospital is not able to heal itself patients, who suffer with anorexia. There is a need for a support from friends, family, but also cooperation with anorexics is an important element of treatment. Another important element is developing facilities which enable patients to have a good therapy in appropriate conditions outside hospitals where it is possible to provide proper assistance without stigmatisation of a patient and with his bigger involvement. 
Polish legislators should follow politicians from other western countries and they should establish penalties for propagating anorexia. An important aspect is also committing a bigger amount of money to health promotion and education. Especially young people should be taught about 'healthy eating' and also about the meaning of physical activity in fighting obesity. Below there are four points with the most important conclusions from our article:

1. The analysis of literature provided in the article has proved that anorexia is not only a disease of our time. The first use of the term anorexia nervosa was in 1874, and first cases similar to anorexia were also described earlier (5th, 8th century). Although, nowadays this disorder occurs much more frequently, it cannot be stated that it is a modern disease.

2. It is hard to diagnose this disease. There are no described clear symptoms and reasons of anorexia.

3. Anorexia is a not enough examined issue in Poland. Providing the new study that performs the rate of occurrence this disease in Poland, appears to be really significant.

4. Pro-ana movement is the phenomenon, which supports anorexics in their activities to reach the dreamedof weight. This movement is very controversial. It is based on the calls of the third feminist wave and as a place of action it includes mainly the Internet. It seems appropriate to carry out scientific research related to the analysis of this movement in the Internet because the one, which was accomplished, was not performed by qualified researchers. That can undermine their credibility. According to the authors of this article, Poland, like other East European countries, should consider the existence of the websites encouraging to anorexia as illegal.

\section{References:}

1. Kędra E, Pietras J. Zaburzenia odżywiania-znak naszych czasów. Probl Hig Epidemiol. 2011; 92(3): 530-534 (in Polish).

2. Nogal P, Lewiński A. Jadłowstręt psychiczny (anorexia nervosa). Endokrynologia Polska. 2008; 59 (2): 148155 (in Polish).

3. Chytra-Gędek W, Kobierecka A. Gotowość anorektyczna u dziewcząt i młodych kobiet. Psychiatria; 2008; 5(1): 7-12 (in Polish).

4. Hepworth J. The social construction of anorexia nervosa. UK: Sage, 1999.

5. Fairburn CG, Cooper Z, Doll HA, Welch SL. Risk Factors for Anorexia Nervosa. Three Integrated Case-Control Comparisions. Arch. Gen. Psychiatry. 1999; 56(5): 468-476.

6. Garner D, Garfinkel P. Socio-cultural factors in the development of anorexia nervosa. Psychol Med. 1980; 10(4): 647-656.

7. Onet.pl, http://kobieta.onet.pl/zdrowie/anoreksja [cited 2015 Nov 15].

8. Bulik CM, Reba L, Siega-Riz AM, Reichborn-Kjennerud T. Anerexia nervosa: definition, epidemiology, and cycle of risk. Int J Eat Disorders. 2005; 37(S1): S2-S9.

9. Jośko J, Kamecka-Krupa J. Czynniki ryzyka anoreksji. Probl Hig Epidemiol. 2007; 88(3): 254-258 (in Polish).

10. Njenga FG, Kangethe RN. Anorexia nervosa in Kenya. East Afr Med J. 2004; 81(4): 188-193.

11. Bennett D, Sharpe M, Freeman C, Carson A, Anorexia nervosa among female secondary school students in Ghana. Br J Psychiatry. 2004; 185(4): 312-317.

12. Trafalska E, Niedźwiecka M, Nowacka E. Czynniki ryzyka zaburzeń odżywiania wśród młodzieży łódzkiejpostrzeganie i kontrola masy ciała. Probl Hig Epidemiol. 2010; 91(4): 602-605 (in Polish).

13. The National Eating Disorders Collaboration, Eating Disorders Prevention, Treatment \& Management: An Evidence Review. Australia 2010.

14. Włodarczyk-Bisaga K. Zaburzenia odżywiania się - rys historyczny, klasyfikacja i obraz kliniczny. Post Psychiatr Neurol. 1993; 2: 43-57 (in Polish).

15. Keel PK, Klump KL Are eating disorders culture-bound syndromes? Implications for conceptualizing their etiology. Psychological Bulletin. 2003; 129(5): 747-769.

16. Żechowski C. Historia badań nad jadłowstrętem psychicznym. Post Psychiatr Neurol. 2004; 13(3): 247-253 (in Polish).

17. Szydłowska J.Pogranicze na talerzu. Rytuał konsumpcji jako wzór kultury i nośniktożsamości pojałtańskiego pogranicza ("Bambino" Ingi Iwasiów). Anthropos? 2010; 14-15: 162-176 (in Polish).

18. Feighner J, Robins E, Guze S. Diagnostic criteria for use in psychiatric research. Arch. Gen. Psychiatry. 1972; 26: 57-63.

19. Blog 1. available from: http://pro-ana-gabson.bloog.pl/?ticaid=6108b3 [cited 2015 Nov 15].

20. Blog 2. available from: http://pro-ana-gabson.bloog.pl/?ticaid=6108b3 [cited 2015 Nov 15]. 
21. Józefik B. Anoreksja i bulimia psychiczna. Kraków: Wydawnictwo Uniwersytetu Jagielońskiego, 1999 (in Polish).

22. Jablow M. Na bakier z jedzeniem. Anoreksja, bulimia, otyłość. Przewodnik dla rodziców. Gdańsk: Gdańskie Wydawnictwo Psychologiczne, 1993 (in Polish).

23. Ziółkowska B. Anoreksja od A do Z. Podręcznik dla nauczycieli i wychowawców. Warszawa: Wydawnictwo Naukowe SCHOLAR, 2005 (in Polish).

24. Polish National Center of Eating Disorders, 2014, [cited 2015 Nov 15]. Zaburzenia odżywiania w liczbach. Available from: http://www.centrumzaburzenodzywiania.pl/zaburzenia-odzywiania-w-liczbach

25. Jaworska M. Gotowość do podjęcia leczenia a poziom wiedzy medycznej u pacjentek z zaburzeniami odżywiania. Curr Prob Psychiatry. 2014; 15 (2): 67-73 (in Polish).

26. Benson TL. W krzywym zwierciadle bulimii. Zaburzenia odżywiania oczami matki i córki. Poznań: Media rodzina, 2010 (in Polish).

27. Polish National Center of Eating Disorders, 2014, [cited 2015 Nov 15]. Leczenie szpitalne osób chorych na anoreksję psychiczną. Available from: http://www.centrumzaburzenodzywiania.pl/

28. Birmingham CL, Su J, Hlynsky JA, Goldner EM, Gao M. The mortality rate from anorexia nervosa. Int J Eat Disorders. 2005; 38(2): 143-146.

29. Sullivan P. Mortality in anorexia nervosa. Am J Psychiatry.1995; 152(7):1073-1074.

30. Signorini A, De Filippo E, Panico S, De Caprio C, Pasanisi F, Contaldo F. Long-term mortality in anorexia nervosa: a report after an 8-year follow-up and a review of the most recent literature. Eur J Clin Nutr. 2007; 61(1): 119-122.

31. Wojtyła A, Biliński P, Bojar I, Wojtyła C. (2011), Zaburzenia odżywiania u polskich gimnazjalistów. Probl Hig Epidemiol. 2011; 92(2): 327-334 (in Polish).

32. Chalcarz W, Merkiel S, Milewska J. Ocena zachowań anorektycznych wśród studentek turystyki i rekreacji. Probl Hig Epidemiol. 2014; 92: 310-316 (in Polish).

33. Dias K. The ana sanctuary: Women's pro-anorexia narratives in cyberspace. J Int Womens Stud. 2013; 4(2): 31-45.

34. Startek I. Motyle w sieci. Krótka charakterystyka ruchu pro - Ana. Curr Prob Psychiatry. 2011; 12(3): 322329 (in Polish).

35. Anty pro ana., 2010, [cited 2015 Nov 15]. Statystycznie rzecz biorąc. Available from: http://antyproana.blox. pl/2010/05/Statystycznie-rzecz-biorac.html

36. Makowska M. Etyczne standardy marketingu farmaceutycznego. Warszawa: CeDeWu, 2010 (in Polish).

37. NBC News. (April 3, 2015), [cited 2015 Nov 15]. Anorexia Crackdown: France Bans Fashion Models Who Are Too Thin. Available from: http://www.nbcnews.com/news/world/anorexia-crackdown-france-bansfashion-models-who-are-too-thin-n335091 